\title{
PEMAHAMAN KONSEP MATEMATIKA MENGGUNAKAN MODEL PEMBELAJARAN PROBLEM BASED LEARNING DAN GROUP INVESTIGATION
}

\author{
${ }^{1)}$ Sitti Fatimah, ${ }^{2)}$ Fitriani Nur, ${ }^{3)}$ Suharti, ${ }^{4)}$ Sri Sulasteri, ${ }^{5)}$ Andi Dian Angriani \\ ${ }^{1,2,3,4,5)}$ Pendidikan Matematika, UIN Alauddin Makassar \\ s.fatimah@uin-alauddin.ac.id ${ }^{1)}$,fitrianinur@uin-alauddin.ac.id ${ }^{2}$, suharti.harti@uin- \\ alauddin.ac.id $^{3}$, sri.sulasteri@uin-alauddin.ac.id ${ }^{4)}$,dian.angriani@uin-alauddin.ac.id ${ }^{5}$
}

\section{Received:}

23-02-2021

Accepted :

03-05-2021

Published:

20-05-2021

\begin{abstract}
This research aims at determining whether there are differences in the understanding of the concept of mathematics students who learn by applying the Problem Based Learning Model with Group Investigation. This research was quasi-experimental design of non-equivalent pretest-posttest control group. The samples were taken from class XI IPA 2 (experimental class I) and class XI IPA 3 (experimental class II). The instrument applied was a learning outcome test containing 5 items. Data were analyzed descriptively and inferentially. The results of the descriptive shows that the mean scores of pre-test was 44.81, and posttest was 76.54 for the experimental class I, while the mean score of pretest of experimental class II was 47.54 and themean score of posttest was 84.14. From the independent sample test, it was obtained a sign score: 0.000 at a significance level of 5\%. This means that $\mathrm{HO}$ is rejected, so it was decided that the level of conceptual understanding for Problem Based Learning model is different from the level of concept understanding in Group Investigation Model. From this research, it is found that the application of the Group Investigation learning model was better than the Problem Based Learning model.
\end{abstract}

Keywords: Understanding Mathematical Concept, Problem Based Learnig, Group Investigation

\begin{abstract}
Abstrak
Tujuan penelitian ini ialah untuk mengetahui ada tidaknya perbedaan pemahaman konsep matematika siswa yang belajar dengan menerapkan model Problem Based Learning dengan Group Investigation. Penelitian ini masuk dalam jenis quasi experiment desain non-equivalent pretest-posttest control group. Sampel yang diambil ialah kelas XI IPA 2 (kelas eksperimen I) dan kelas XI IPA 3 (kelas eksperimen II). Instrumen yang diterapkan berupa tes hasil belajar berisi 5 item. Analisis data dihitung menggunakan teknik analisis: deskriptif dan juga inferensial. Hasil dari data deskriptif didapatkan nilia rerata sebesar 44,81 pretest dan 76,54 posttest untuk kelas eksperimen I, sedangkan pada kelas eksperimen II mendapat skor 47,54 pretest dan 84,14 posttest. Dari pengujian independent sample test didapatkan skor sign: 0,000 pada taraf signifikansi 5\%. Ini artinya $\mathrm{H}_{0}$ ditolak, jadi diputuskan bahwa tingkatan kemampuan pemahaman konsep untuk model Problrm Based Learning berbeda dengan tingkat pemahaman konsep pada model Group Investigation. Dari penelitian ini terkait pemahaman konsep matematika siswa diperoleh penerapan model pembelajaran Group Investigation lebih baik dari pada model pembelajaran Problem Based Learning.
\end{abstract}

Kata Kunci: Pemahaman Konsep, Problem Based Learning, Group Invertigation

\section{Pendahuluan}

Matematika merupakan mata pelajaran yang wajib disetiap jenjang pendidikan. Menurut Arta, Japa, dan Sudarma (2020) matematika adalah sebuah bidang ilmu yang mengandung konsep-konsep abstrak dan disusun secara sistematis untuk memberikan 
pengalaman bernalar kepada peserta didik. Matematika dijadikan landasan pada ilmu lain dalam berbagai aspek kehidupan (Fitriatien, 2019). Tujuan pendidikan matematika berdasarkan Permendiknas Nomor 22 Tahun 2006, kompetensi matematika intinya memuat keterampilan berupa: (1) pemahaman konsep matematis, (2) menggunakan penalaran, (3) memecahkan masalah, (4) mengomunikasikan gagasan, dan (5) memiliki sifat menghargai kegunaan matematika (Ningsih, 2016).

Menurut Rahayu, Rohaeti, dan Yuliani (2018) kemampuan pemahaman konsep matematik merupakan kemampuan siswa untuk mengingat sebuah konsep dan dapat menjelaskan dengan bahasa sendiri serta mampu menerapkan konsep tersebut pada sebuah permasalahan, kemudian dapat menghubungkan satu konsep dengan konsep lainnya. Terdapat juga indikator untuk menilai kemampuan siswa memahami konsep matematika yang diambil dari NCTM dalam Febriani, Widada, dan Herawaty (2019) adalah 1) Menafsirkan konsep baik verbal maupun tulisan, 2) Mengidentifikasi serta membuat contoh ataupun bukan contoh, 3) Menerapkan model, simbol, serta diagram dalam memaparkan konsep, 4) Merepresentasikan ke dalam bentuk berbeda, 5) Memaknai interpretasi konsep, 6) Mendapati berbagai sifat suatu konsep sekaligus mengenal syarat dalam menentukan konsep, 7) Memadankan sekaligus membedakan beberapa konsep.

Pentingnya kemampuan dalam memahami konsep tidak didukung dengan kondisi siswa saat ini. Pemahaman mereka dalam hal ini masih dikatakan rendah, baik itu pada tingkat dasar ataupun menengah (Jeheman, Gunur, \& Jelatu, 2019; Kartika, 2018; Ranti \& Kurniati, 2020). Demikian juga yang diungkapkan oleh (Rahayu \& Kusuma, 2019) bahwa siswa mengalami kesulitan untuk menghubungkan berbagai konsep matematika dengan peristiwa keseharian mereka. Hal ini disebabkan karena objek matematika yang bersifat abstrak. Oleh karena itu, diperlukan upaya dalam mengatasi hal tersebut, antara lain penerapan model pembelajaran Problem Based Learning (PBL) dan Group Investigation (GI).

Problem Based Learning (PBL) yang dikenal dengan pembelajaran berlandaskan masalah merupakan pendekatan dalam pendidikan yang maksudnya membantu para siswa menemukan masalah secara nyata, mengumpulkan informasi dengan strategi yang ditentukan sendiri dan membuat suatu keputusan (Timor, Ambiyar, Dakhi, Verawadina, \& Zagoto, 2021). PBL menolong peserta didik meningkatkan keterampilan mereka dalam hal berpikir secara kritis dan menyelesaikan permasalahan (Agustina, 2018). 
Sementara itu, model pembelajaran Group Investigation (GI) ialah pembelajaran yang lebih mengarah pada investigasi kelompok (Fadilah, Haloman, \& Priyanda, 2020). Pada model pembelajaran Group Investigation (GI) siswa diminta agar aktif dalam menyelesaikan tiap masalah yang ditugaskan oleh pendidik dengan membentuk kelompok dan berdiskusi bersama (Tsani, Huda, Yasin, Syazali, Sari, \& Jermsittiparsert, 2020). Sedangkan menurut Siregar (2019), pembelajaran kooperatif group investigation (GI) bukan sekedar membantu para siswa mengembangkan keterampilan bekerjasama, berfikir secara kritis, serta sikap bersosialisasi, namun juga membantu mereka untuk memahami sebuah konsep.

Berdasarkan hasil penelitian sebelumnya oleh Anggrainia, Alzaberb, Effendic (2019) menyimpulkan bahwa pembelajaran PBL dalam pelajaran matematika memperbaiki rangkaian pembelajaran serta meningkatkan hasil belajar para siswa. Penelitian Kurniawati, Supandi, dan Aini (2020) menjelaskan bahwa model pembelajaran PBL lebih unggul dari konvensional pada aspek keterampilan berpikir kritis siwa. PBL juga mengubah minat dan prestasi belajar siswa menjadi lebih baik (Mashuri, Djidu, \& Ningrum, 2019). Demikian juga dengan penelitian tentang model pembelajaran GI, disimpulkan bahwa pengaplikasian Group Investigation lebih unggul daripada pengaplikasian pembelajaran secara konvensional (Tsani, Huda, Yasin, Syazali, Sari, \& Jermsittiparsert, 2020). Menurut Pranata (2016), model pembelajaran yang akurat dalam meningkatkan keterampilan siswa memahami konsep ialah model GI. Hal ini sejalan dengan penelitian Darmayanti, Wati, Sudirman, \& Wijaya (2020) yang menyimpulkan pembelajaran kooperatif untuk tipe GI pada LKS materi kalor efektif memperbaiki pemahaman konsep para siswa. Dengan demikian, target dari penelitian ini untuk membandingkan pemahaman siswa dari segi konsep matematika siswa menggunakan model PBL dan model GI.

\section{Metode Penelitian}

Penelitian ini masuk dalam jenis quasi experiment desain non-equivalent pretest-posttest control group. Pada desain ini, kelompok eksperimen I dan kelompok eksperimen II tidak dipilih secara acak dan kedua kelompok dibandingkan. Kedua kelompok diberikan pretest kemudian diberikan perlakuan, dan terakhir diberikan posttest. Populasi yang diambil adalah siswa ditingkatan kelas XI IPA dari MAN 1 Makassar yang jumlahnya 186 siswa. Sampel yang ditetapkan dengan purposive sampling karena dengan menggunakan teknik penyampelan ini diharapkan kriteria 
sampel yang diperoleh benar-benar sesuai dengan penelitian yang akan dilakukan. Kelas

XI IPA 3 sebagai kelas eksperimen I yang menerapkan Problem Based Learning, dan

XI IPA 2 sebagai kelas eksperimen II yang menerapkan pembelajaran Group

Investigation. Instrumen yang digunakan berupa tes hasil belajar bentuk isian sebanyak 5 nomor, kemudian dianalisis secara deskriptif dan juga secara inferensial.

\section{Hasil dan Pembahasan}

Berdasarkan rangkaian penelitian yang dilakukan, maka didapatkan data yang termuat pada tabel di bawah:

Tabel 1. Hasil Pretest dan Posttest Kemampuan Pemahaman Konsep Siswa Kelas Eksperimen I

\begin{tabular}{ccc}
\hline Statistic & Pretest & Nilai \\
\hline Jumlah sampel & 37 & Posttest \\
Nilai terendah & 30 & 37 \\
Nilai tertinggi & 60 & 60 \\
Nilai rerata & 44,81 & 85 \\
Standar deviasi & 8,54 & 76,54 \\
\end{tabular}

Dari data di atas, nilai rerata untuk hasil tes pemahaman siswa pada suatu konsep dalam kelas eksperimen I ada peningkatan setelah diberikan perlakuan, yakni nilai rerata pretest dari 44,81 menjadi 76,54 saat posttest, ada selisih yang cukup jauh yakni 31,73 .

Apabila hasil dari tes peserta didik dikategorikan dalam kelompok rendah, sedang, dan tinggi, maka diperoleh frekuensi dari kelas eksperimen I setelah prestest dan posttest. Gambar 1 berikut ini merupakan grafik dari hasil tes untuk kelas eksperimen I.

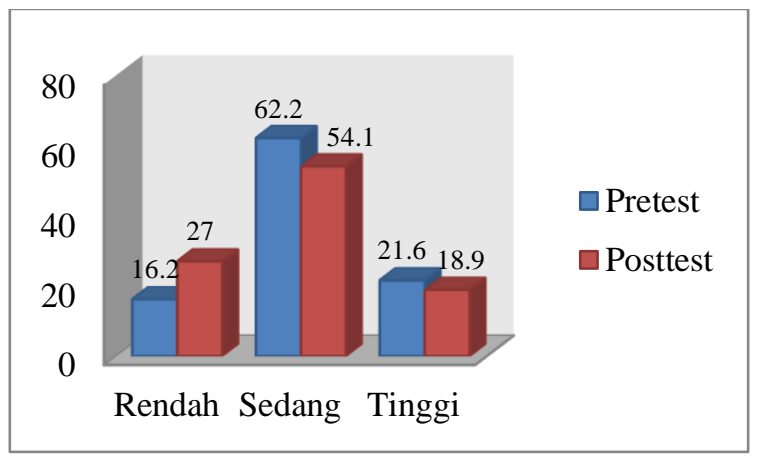

Gambar 1. Persentase Kemampuan Pemahaman Konsep Prestest dan Posttest Kelas Eksperimen I 
Dari gambar yang ada di atas, bisa dinyatakan hasil tes peserta didik dalam mengukur pemahaman konsep mereka, diketahui 6 peserta didik saat pretest masuk kategori rendah, 23 peseta didik masuk kategori sedang, dan 8 peserta didik masuk kategori tinggi. Selanjutnya dari gambar tersebut juga bisa diketahui bahwa hasil tes pada saat posttest diperoleh 10 peserta didik masuk kategori rendah, 20 orang masuk kategori sedang, dan 7 orang masuk kategori tinggi. Dengan demikian, bisa diputuskan bahwa hasil dari tes kemampuan pemahaman konsep matematika peserta didik pada pretest dan posttest dalam kelas eksperimen I masuk dalam kriteria sedang.

Tabel 2. Kemampuan Pemahaman Konsep Siswa Kelas Eksperimen I

\begin{tabular}{lc}
\hline \multicolumn{1}{c}{ Indikator Pemahaman Konsep } & Banyak Siswa yang Lulus \\
\hline $\begin{array}{l}\text { Menyatakan ulang sebuah konsep } \\
\text { Menyajikan konsep dalam berbagai } \\
\text { bentuk representasi matematis }\end{array}$ & 36 siswa \\
$\begin{array}{l}\text { Menggunakan, memanfaatkan, dan } \\
\text { memilih prosedur atau operasi tertentu }\end{array}$ & 30 siswa \\
$\begin{array}{l}\text { Mengembangkan syarat perlu dan } \\
\text { syarat cukup sebuah konsep }\end{array}$ & 30 siswa \\
$\begin{array}{l}\text { Mengaplikasikan konsep atau } \\
\text { algoritma dalam pemecahan masalah }\end{array}$ & 20 siswa \\
\hline
\end{tabular}

Dari tabel di atas, dapat diketahui indikator untuk menilai pemahaman konsep siswa dalam pelajaran matematika yang mampu dijawab peserta didik yaitu ada 36 orang memenuhi indikator pertama, terdapat 30 orang memenuhi indikator ke-2, terdapat 23 orang memenuhi indikator ke-3, terdapat 30 orang memenuhi indikator ke4, dan terdapat 18 orang memenuhi indikator ke-5. Dengan demikian, dapat disimpulkan bahwa frekuensi terkecil dari banyaknya siswa yang lulus pada tes ini dilihat dari pencapaian indikator ialah indikator ke-5 yakni menerapkan algoritma ketika memecahkan masalah, dengan kata lain indikator ke-5 adalah pencapaian yang mayoritas siswa belum bisa memenuhinya. 
Selanjutnya berdasarkan tes awal dan akhir dalam kelas eksperimen II diperoleh hasil di bawah ini:

Tabel 3. Hasil Pretest dan Posttest kemampuan pemahaman konsep siswa Kelas Eksperimen II

\begin{tabular}{ccc}
\hline & \multicolumn{2}{c}{ Nilai } \\
\cline { 2 - 3 } Statistik & Pretest & Posttest \\
\hline Jumlah Sampel & 37 & 37 \\
Nilai Terendah & 30 & 75 \\
Nilai Tertinggi & 60 & 95 \\
Nilai rata-rata & 47,54 & 84,14 \\
Standar Deviasi & 7,515 & 5,012 \\
\hline
\end{tabular}

Berdasarkan tabel di atas, perolehan pada tes awal (pretest) dan tes akhir (posttest) dari kelas eksperimen II mengalami peningkatan yakni dengan nilai rerata dari 47,54 menjadi 84,14, perolehan nilai ini mempunyai selisih 36,6.

Apabila hasil dari tes peserta didik dikategorikan rendah, sedang, serta tinggi, maka diperoleh untuk frekuensi kelas eksperimen II seperti pada gambar 2 berikut ini.

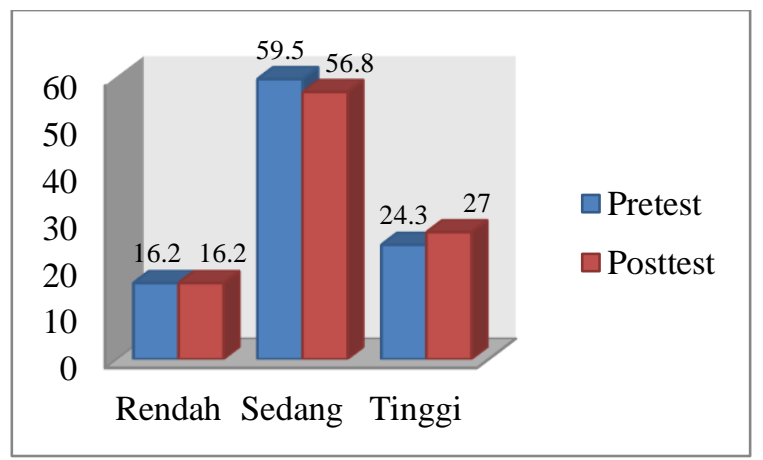

Gambar 2. Persentase Kemampuan Pemahaman Konsep Prestest dan Posttest Kelas Eksperimen II

Dari gambar yang ada di atas, bisa dinyatakan bahwa untuk hasil pada tes pemahaman konsep peserta didik di tes awal (pretest), ada 6 siswa yang masuk kategori rendah, 22 orang yang masuk kategori sedang, dan 9 orang yang masuk kategori tinggi. Selanjutnya dari gambar tersebut juga bisa dilihat bahwa untuk hasil saat tes akhir (posttest) memperoleh 6 siswa masuk kategori rendah, 21 orang masuk kategori sedang, dan 10 orang masuk kategori tinggi. Dengan demikian, diputuskan bahwa dalam tes didapatkan perolehan nilai pada siswa di kelas eksperimen II masuk dalam kategori yang sedang. 
Tabel 4. Kemampuan Pemahaman Konsep Siswa Kelas Eksperimen II

\begin{tabular}{lc}
\hline \multicolumn{1}{c}{ Indikator Pemahaman Konsep } & Banyak Siswa yang Lulus \\
\hline $\begin{array}{l}\text { Menyatakan ulang konsep } \\
\text { Menyajikan konsep dalam berbagai } \\
\text { bentuk representasi matematis }\end{array}$ & 36 siswa \\
$\begin{array}{l}\text { Menggunakan, memanfaatkan, dan } \\
\text { memilih prosedur atau operasi tertentu }\end{array}$ & 34 siswa \\
$\begin{array}{l}\text { Mengembangkan syarat perlu dan syarat } \\
\text { cukup suatu konsep }\end{array}$ & 25 siswa \\
$\begin{array}{l}\text { Mengaplikasikan konsep atau algoritma } \\
\text { dalam pemecahan masalah }\end{array}$ & 30 siswa \\
\hline
\end{tabular}

Dari tabel di atas, dapat diketahui tolak ukur dari pemahaman konsep matematika yang bisa tercapai yaitu 36 siswa yang memenuhi indikator pertama, 34 siswa yang memenuhi indikator ke-2, 25 siswa yang memenuhi indikator ke-3, 30 siswa yang memenuhi indikator ke-4, dan terdapat 20 siswa yang memenuhi indokator ke-5. Dengan demikian, dapat disimpulkan bahwa frekuensi terkecil dari banyaknya siswa yang lulus pada tes berdasarkan tolak ukur yang ditetapkan diketahui indikator ke-5 yang masih banyak yang belum dicapai oleh siswa, yakni menerapkan konsep saat memecahkan masalah.

Setelah pengujian prasyarat berupa uji normalitas dan homogen, maka kesimpulan yang diperoleh ialah data sudah normal dan homogen. Selanjutnya berdasarkan pengujian hipotesis yang menggunakan uji independent sample test dengan signifikansi $5 \%$ atau 0,05. Dari perhitungan SPSS versi 20 maka nilai sig(2-tailed) yang didapat adalah 0,001 , berarti $\mathrm{H}_{0}$ ditolak sebab nilai sig $<\alpha$. Artinya pemahaman konsep matematika peserta didik bagi yang belajar dengan model Problem Based Learning berbeda dengan yang belajar menggunakan model Group Investigation.

Dari hasil yang didapat pada pretest dan posttest untuk kelas eksperimen I mendapat skor rerata yang meningkat setelah ada perlakuan. Artinya bisa dikatakan terjadi peningkatan pada hasil belajar siswa yang begitu signifikan hingga mencapai $41,45 \%$. Capian ini didukung teori konstruktivisme, peserta didik yang dipacu agar bisa mengembangkan pemahamannya sendiri. Pembelajaran dengan model Problem Based Learning yang menitikberatkan pelaku pembelajaran dalam hal ini siswa sebagai pembelajar, jadi siswa bisa meningkatkan pemahaman konsep mereka melalui pembelajaran ini. 
Dari hasil pretest dan posttest dalam kelas eksperimen II didapatkan skor rerata para siswa meningkat setelah ada perlakuan. Berarti bisa dikatakan ada perubahan yang signifikan dalam hasil belajar siswa yang mencapai 43,49\%. Pencapaian ini didukung teori Vigotsky yakni pendidikan sebagai usaha sosial. Pada model pembelajaran GI, pembelajaran ini mengajarkan peserta didik untuk mempunyai keterampilan yang baik ketika berkomunikasi ataupun keterampilan ketika kegiatan kelompok, memberikan kesempatan untuk peserta didik lebih berpikir mandiri, mencari sumber belajar sendiri, menemukan konsep dari materi pelajaran dengan cara investigasi. Hal ini membuktikan bahwa Group Investigation bisa meningkatkan pemahaman konsep siswa.

Penelitian relevan dilakukan oleh Ningsi (2016), menyimpulkan bahwa keterampilan siswa memahami konsep lebih bagus saat mengaplikasikan pembelajaran PBL dari sebelumnya untuk materi pokok statistika. Demikian juga Kusuma (2015), menunjukkan bahwa pembelajaran tipe Group Investigation dilengkapi dengan Metode Gallery Learning lebih efektif dari pada menggunakan model pembelajaran konvensional terhadap pemahaman konsep matematika siswa dan aktivitas siswa.

Berdasarkan beberapa kajian referensi dan penelitian sebelumnnya diperoleh model pembelajaran Problem Based Learning dan model pemebelajaran Group Investigation relevan digunakan dalam pembelajaran matematika, namun untuk memahamkan konsep matematika siswa didapatkan model pembelajaran Group Investigation lebih baik dibandingkan menggunakan model pembelajaran Problem Based Learning.

\section{Kesimpulan dan Saran}

Kesimpulan yang diperoleh ialah adanya perbedaan kemampuan pemahaman konsep matematika siswa melalui penerapan model Problem Based Learning dengan model pembelajaran Group Investigation. Namun demikian, kedua model tersebut relevan diterapkan dalam pembelajaran matematika.

\section{Pustaka}

Agustina, J. (2018). Penerapan Model Pembelajaran Problem Based Learning (PBL) untuk Meningkatkan Kemampuan Pemahaman Konsep Matematis Mahasiswa S1 Tadris Matematika IAIN Bengkulu. Jurnal Equation: Teori Dan Penelitian Pendidikan Matematika, 1(1), 25-38. https://doi.org/dx.doi.org/10.29300/equation.v1i1.1344

Anggrainia, N., Alzaberb, \& Effendi, L. A. (2019). Penerapan Model Pembelajaran 
Berdasarkan Masalah (Problem Based Learning) untuk Meningkatkan Hasil Belajar Matematika Siswa Kelas VIII2SMPN 34 Pekanbaru. AKSIOMATIK: Jurnal Pendidikan Dan Pembelajaran Matematika, 7(1), 1-9.

Arta, I. M., Japa, I. G. N., \& Sudarma, I. K. (2020). Problem Based Learning Berbantuan Icebreaker Berpengaruh Terhadap Kemampuan Pemecahan Masalah Matematika. Mimbar PGSD Undiksha, 8(2), 264-273. https://doi.org/dx.doi.org/10.23887/jjpgsd.v8i2.25435

Darmayanti, N. W. S., Wati, D. P. A. J., Sudirman, I. N., \& Wijaya, I. K. W. B. (2020). Efektivitas Model Pembelajaran Kooperatif Tipe Group Investigation (GI) Berbantuan LKS (Lembar Kerja Siswa) Pada Materi Kalor Untuk Meningkatkan Pemahaman Konsep Siswa SD Kelas V. ORBITA: Jurnal Kajian, Inovasi, Dan Aplikasi Pendidikan Fisika, 6(1), 159-164. https://doi.org/10.31764/orbita.v6i1.2152

Fadilah, Haloman, T. ., \& Priyanda, R. (2020). The Effectiveness of Using the Group Investigation Model in Improving Mathematics Motivation in SMK Dwi Tunggal 1 Tanjung Morawa. Jurnal Dimensi Matematika, 3(01), 154-163. https://doi.org/10.33059/jdm.v3i01.2342

Febriani, P., Widada, W., \& Herawaty, D. (2019). Pengaruh Pembelajaran Matematika Realistik Berbasis Etnomatematika Terhadap Kemampuan Pemahaman Konsep Matematika Siswa SMA Kota Bengkulu. Jurnal Pendidikan Matematika Raflesia, $4(2), 120-135$.

Fitriatien, S. R. (2019). Analisis Kesalahan dalam Menyelesaikan Soal Cerita Matematika Berdasarkan Newman. Jurnal Ilmiah Pendidikan Matematika, 4(1), $53-64$.

Jeheman, A. A., Gunur, B., \& Jelatu, S. (2019). Pengaruh Pendekatan Matematika Realistik terhadap Pemahaman Konsep Matematika Siswa. Mosharafa: Jurnal Pendidikan Matematika, 8(2), 191-202. https://doi.org/10.31980/mosharafa.v8i2.454

Kartika, Y. (2018). Analisis Kemampuan Pemahaman Konsep Matematis Peserta Didik Kelas VII SMP Pada Materi Bentuk Aljabar. Jurnal Pendidikan Tambusai, 2(4), 777-785.

Kurniawati, W., Supandi, \& Aini, A. N. (2020). Efektivitas Model Pembelajaran Problem Based Learning (PBL) dan Model Pembelajaran Pair Check Terhadap Kemampuan Berpikir Kritis Matematis Siswa Kelas VII. Imajiner: Jurnal Matematika Dan Pendidikan Matematika, 2(5), 428-438. https://doi.org/10.26877/imajiner.v2i5.6665

Kusuma, A. S. (2015). Efektivitas Pembelajaran Kooperati Tipe GI (group Investigation) Dilengkapi dengan Metode Gallery Learning terhadap Pemahaman Konsep dan Aktivitas Siswa. Universitas Islam Negeri Sunan Kalijaga Yogyakarta.

Mashuri, S., Djidu, H., \& Ningrum, R. K. (2019). Problem-based learningdalam pembelajaran matematika: Upaya guru untuk meningkatkan minat dan prestasi belajar siswa. PYTHAGORAS: Jurnal Pendidikan Matematika, 14(2), 112-125. https://doi.org/10.21831/pg.v14i2.25034 
Ningsi, E. R. (2016). Efektivitas Pembelajaran Problem Based Learning (PBL) terhadap Kemampuan Pemahamaan Konsep Matematika Siswa pada Materi Statistika. Universitas Nusantara Persatuan Kediri.

Ningsih, Y. L. (2016). Kemampuan Pemahaman Konsep Matematika Mahasiswa Melalui Penerapan Lembar Aktivitas Mahasiswa (LAM) Berbasis Teori APOS Pada Materi Turunan. Edumatica: Jurnal Pendidikan Matematika, 6(01), 1-8. https://doi.org/10.22437/edumatica.v6i01.2994

Pranata, E. (2016). Implementasi Model Pembelajaran Group Investigation (GI) Berbantuan Alat Peraga untuk Meningkatkan Kemampuan Pemahaman Konsep Matematika. JPMI (Jurnal Pendidikan Matematika Indonesia), 1(1), 34-38. https://doi.org/dx.doi.org/10.26737/jpmi.v1i1.80

Rahayu, L. D., \& Kusuma, A. B. (2019). Peran Pendidikan Matematika di Era Globalisasi. Prosiding Sendika: Bidang Matematika, 5(1).

Rahayu, W. D., Rohaeti, E. E., \& Yuliani, A. (2018). Analisis Kemampuan Pemahaman Matematik Siswa MTs di Kabupaten Bandung Barat. Jurnal Math Educator Nusantara: Wahana Publikasi Karya Tulis Ilmiah Di Bidang Pendidikan Matematika, 4(1), 79-86. https://doi.org/10.29407/jmen.v4i01.11998

Ranti, F., \& Kurniati, A. (2020). Pengaruh Penerapan Model Pembelajaran Group Investigation (GI) terhadap Pemahaman Konsep Matematis Siswa berdasarkan Self-Efficacy Siswa SMP/MTs. JURING (Journal for Research in Mathematics Learning), 3(1), 021-030.

Siregar, R. M. R. (2019). Pengaruh Model Pembelajaran Kooperatif Tipe Group Investigation Terhadap Pemahaman Konsep Matematis. Jurnal Serunai Matematika, 11(1), 60-67. https://doi.org/10.37755/jsm.v11i1.110

Timor, A. R., Ambiyar, Dakhi, O., Verawadina, U., \& Zagoto, M. M. (2021). Effectiveness of Problem-Based Model Learning on Learning Outcomes and Student Learning Motivation in Basic Electronic Subjects. International Journal of Multiscience, 1(10).

Tsani, I., Huda, S., Yasin, M., Syazali, M., Sari, W. R., \& Jermsittiparsert, K. (2020). The Impact of Group Investigation (GI) Learning Models on Sequence and Series: A Study Case Numerical Skills Analysis in Islamic Boarding School. Journal of Physics: Conference Series, $1467 . \quad$ https://doi.org/10.1088/17426596/1467/1/012030 